\title{
Coating agents - a vision of clustering index comparison in the direct reduction stakeholders
}

\begin{abstract}
This paper presents a vision of clustering concerns and the searching for the best anticlustering solutions, considering the vision of the iron ore pellets producers and DRI producers, as well. The test was carried out considering the general procedure of ISO 11256:2015 Iron ore pellets for shaft direct-reduction feedstocks - Determination of the clustering index, and, considering modification in the test temperature.
\end{abstract}

Keywords: clustering, welding, coating agents, stakeholders, clogging, pellets
Volume 5 Issue I - 202I

\author{
Ottavio Raul Carmignano \\ Universidade Federal de Minas Gerais, Brazil
}

Correspondence: Ottavio Raul Carmignano, Innovation Ph.D. Student, Universidade Federal de Minas Gerais, Brazil, Email ottaviocarmignano@gmail.com

Received: December 14,2020| Published: March 19, 2021

\section{Discussion}

The clustering phenomenon consists of a kind of welding between particles generated during the reduction process sticking pellets/lump each other and/or in the refractory wear. High reducing gas temperature is required to boost productivity, and on the other hand, can contribute to the clustering occurrence affecting the reactor performance. By observing, clusters at the exit conveyor belt it is possible to keep the reactor running and take corrective actions. Sometimes the bed permeability is affected, demanding a planned stoppage to fix some problem. However, the worst scenario is a non-planned stoppage, which can ignite a clustering crisis. The majority of DRI producers face this phenomenon and restriction regarding different iron ore pellet/ lump quality/suppliers, blend mix participations were individually established and for sure the optimum reducing gas temperature was designed considering the blend mix participations and the DHI quality has been established, as well. And, an alternative to control clustering is using coating agents in iron ore pellets. The usual anticlustering agents are dolomite, limestone, bauxite, olivine, talc, and cement, at a proportion of $4,0 \mathrm{kgs}$ per ton, sprayed in a water solution on the conveyor belt. ${ }^{1}$ However, the clustering index for the minerals dolomite and bauxite are considered high - and if the temperature goes from $950^{\circ} \mathrm{C}$ instead of the $850^{\circ} \mathrm{C}$ determined by ISO 11256 , the clustering index goes two or three times higher. ${ }^{2}$

The cement solution, by its turn, presents an interesting cluster index but presents operational difficulties, such as difficulty applying and pipe clogging. Thus, the study of new materials is relevant, and companies and universities start experimenting with new materials as anti-clustering agents, like metamorphic rocks. Graphic one shows some numbers for cluster index from traditional materials and metamorphic rocks; in addition, a material developed by Pedras Congonhas Ltda was used, here called PC Coating agent (Figure 1). The test results are very interesting. As it is possible to be noticed at $850^{\circ} \mathrm{C}$, as requested by ISO 11256 , there is no significant difference in the sticking index between the different coating agents. On the other hand, considering the temperature modification of $950^{\circ} \mathrm{C}$, which better represents the Direct Reduction Process, according to some DRI producers, it is possible the notice the effect of the test temperature on the clustering performance, and the best performance was obtained with the use of the PC Coating agent. Also, note that it is possible to use only $2,5 \mathrm{kgs}$ per ton of iron ore pellet. Preliminary tests show similar performance between cement and PC Coating agents, as shown in Figure $2 \&$ Table 1.
Clustering Index for different coating (\%)

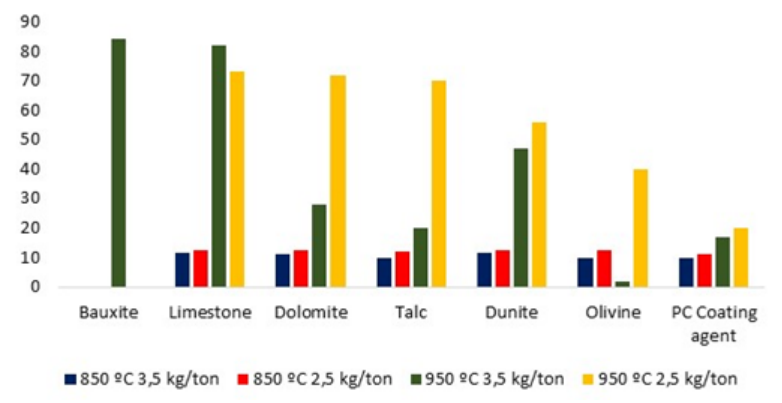

Figure I Adapted from Pereira, Evaluation of the use of different materials for reduction of sticking tendency of the pellets during the direct reduction process, 2012

\section{Clustering index $-950 \circ \mathrm{C}$}

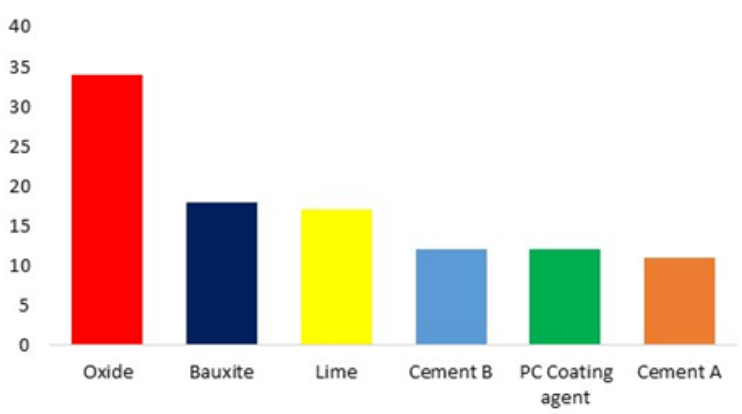

Figure 2 Data obtained in a research center of a pellet consuming company, 2018.

Table I Data obtained in a research center of a direct reduction reactor producer, 2018

\begin{tabular}{llll}
\hline $\begin{array}{l}\text { \% Pellet } \\
\text { coated }\end{array}$ & $\begin{array}{l}\text { \% Pellet } \\
\text { uncoated }\end{array}$ & Cement & $\begin{array}{l}\text { PC coating } \\
\text { agent }\end{array}$ \\
\hline 0 & 100 & 94 & 94 \\
25 & 75 & 88 & 69 \\
50 & 50 & 59 & 38 \\
75 & 25 & 26 & 17 \\
100 & 0 & 14 & 11 \\
\hline
\end{tabular}




\section{Conclusion}

Thus, the anti-clustering solution developed by Pedras Congonhas is very effective in clustering prevention even with high reducing gas temperature and consequently allowing a safe and very productive performance of the Reduction Director Reactor.

\section{Acknowledgments}

None.

\section{Conflicts of interest}

The author declared that there is no conflict of interest.

\section{References}

1. Pereira JG. Evaluation of the use of different materials to reduce the bounding tendency pellets during the direct reduction process. Brazil. UFMG, Minas Gerais; 2012.

2. Sterneland J, Jonsson PG. The use of coated pellets in optimizing the blast furnace operation. ISIJ International. 2003;43(1):26-35. 